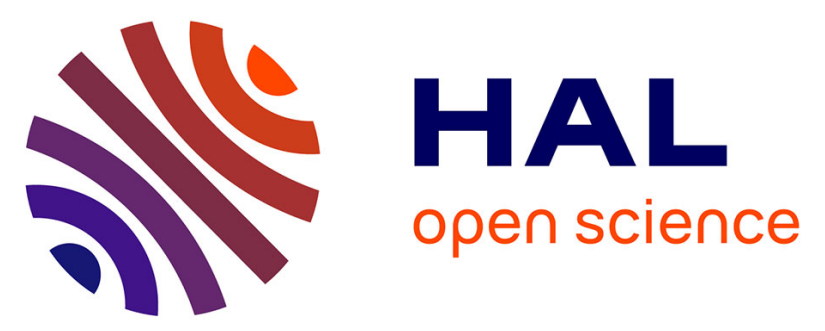

\title{
Kuniesaurus albiauris, a New Genus and Species of Scincid Lizard from the Île des Pins, New Caledonia, with Comments on the Diversity and Affinities of the Region's Lizard Fauna
}

Ross Sadlier, Matthias Deuss, Aaron Bauer, Hervé Jourdan

\section{To cite this version:}

Ross Sadlier, Matthias Deuss, Aaron Bauer, Hervé Jourdan. Kuniesaurus albiauris, a New Genus and Species of Scincid Lizard from the Île des Pins, New Caledonia, with Comments on the Diversity and Affinities of the Region's Lizard Fauna. Pacific Science, 2019, 73 (1), pp.123-141. 10.2984/73.1.6 . hal-02496892

\section{HAL Id: hal-02496892 \\ https://hal.science/hal-02496892}

Submitted on 16 Mar 2020

HAL is a multi-disciplinary open access archive for the deposit and dissemination of scientific research documents, whether they are published or not. The documents may come from teaching and research institutions in France or abroad, or from public or private research centers.
L'archive ouverte pluridisciplinaire HAL, est destinée au dépôt et à la diffusion de documents scientifiques de niveau recherche, publiés ou non, émanant des établissements d'enseignement et de recherche français ou étrangers, des laboratoires publics ou privés. 


\title{
Kuniesaurus albiauris, a New Genus and Species of Scincid Lizard from the Île des Pins, New Caledonia, with Comments on the Diversity and Affinities of the Region's Lizard Fauna ${ }^{1}$
}

\author{
Ross A. Sadlier, ${ }^{2,6}$ Matthias Deuss, ${ }^{3}$ Aaron M. Bauer, ${ }^{4}$ and Hervé Jourdan ${ }^{5}$
}

\begin{abstract}
A new genus and species of skink, Kuniesaurus albiauris, is here described from the Ille des Pins off southern New Caledonia. This new taxon possesses a unique suite of morphological apomorphies (scalation) that does not allow it to be placed in any existing Australasian eugongylid genus. It is known only from a single area in dense coastal forest on limestone, on the main island of the Île des Pins. The species area of occupancy is restricted, and the habitat occupied under threat from the spread of the highly invasive Little Red Fire Ant Wasmannia auropunctata. These factors place this new skink at a level of risk sufficient for it to be listed as Critically Endangered under IUCN Red List criteria. The affinities of the lizard fauna of the Île des Pins with respect to that present on southern New Caledonia are also discussed, most notably the absence from the Île des Pins of taxa typically restricted to ultramafic surfaces.
\end{abstract}

Keywords: Scincidae, systematics, new species, biogeography, conservation

The ILE DEs PINS is a moderately large island $\left(\sim 150 \mathrm{~km}^{2}\right), 50 \mathrm{~km}$ south of New Caledonia's main island, the Grande Terre, from which it is separated by a shallow series of straits, reefs, lagoons, and passes. Although currently separated, these two landmasses have experienced repeated land-bridge connection and disjunction with fluctuating sea level over the Pleistocene period (Pelletier 2007). Surrounding the Ile des Pins itself are a number

\footnotetext{
${ }^{2}$ Australian Museum Research Institute, Australian Museum, Sydney, Australia.

${ }^{3}$ Independent naturalist—matthias.deuss@gmail.com.

${ }^{4}$ Department of Biology, Villanova University, 800

Lancaster Avenue, Villanova, Pennsylvania 19085, USA.

${ }^{5}$ Aix-Marseille Université, Université of d'Avignon, CNRS, IRD, IMBE (Institut Méditerranéen de Biodiversité et d'Ecologie marine et continentale), Centre IRD Nouméa-BPA5, 98848 Nouméa Cedex, New Caledonia.

${ }^{6}$ Corresponding author (e-mail: ross.sadlier@ bigpond.com).
}

of small satellite islands. These islands are raised fossil coral heads formed ca. 118,000 B. P. (Dubois et al. 1974) and mostly emergent since the end of the Pleistocene (Balouet and Olson 1989). They reach no more than $20 \mathrm{~m}$ in elevation.

Field research on the Île des Pins in 1990 by Bauer and Sadlier resulted in the first comprehensive overview of the island's lizard fauna (Bauer and Sadlier 1994), but was both short in duration and limited in scope, being largely restricted to coastal habitats on the west side of the island. A comprehensive study of the lizards of the satellite islands surrounding Île des Pins was undertaken by Geneva between 2000 and 2003, resulting in an updated overview of the region's herpetofauna (Geneva et al. 2013). Independent studies by Ineich of the Muséum National d'Histoire Naturelle, Paris (MNHN) resulted in the rediscovery of the giant skink Phoboscincus bocourti on one of the small islets (Ineich 2009) after the species had been "lost" to science for nearly 150 years. These field studies in combination resulted in the recognition of a moderately rich lizard fauna of nine skinks and eight diplodactylid geckos (Geneva et al. 2013). More recently (2011-2014) field 
surveys by the Institut Méditerranéen de Biodiversité et d'Ecologie marine et continentale (IMBE) lab team (HJ coordinator), supported by the Province Sud, have been undertaken to document the extent and impact of invasive species (rodents, feral cats, and exotic ants) on the satellite islands surrounding Île des Pins, and to a lesser extent the main island, with an emphasis on their impact on the region's lizard fauna. These field studies have resulted in significant new records for the offshore islands in the region, and also investigated forest remnants on ultramafic surfaces of the main island (Jourdan et al. 2011, 2012, 2013, and 2014).

In 2015, a small skink, clearly representing an undescribed taxon, was found opportunistically on the main island, in the Touete tribal region. Most significantly, this new species could not be assigned to any of the existing genera of New Caledonian scincid lizards, or to any existing Australasian genus. The discovery of this uniquely divergent species, indicating that the evolutionary history of the lizard fauna of the Île des Pins is far more complex than initially thought, contributes significantly to the region's biodiversity value. The suite of morphological apomorphies in scalation unique to the new species identify it as an evolutionary lineage distinct from other genera of skinks, and a new genus is required to accommodate it.

\section{MATERIALS AND METHODS}

Abbreviations: Institutional abbreviationsMNHN (Muséum National d'Histoire Naturelle, Paris); IMBE (Institut Méditerranéen de Biodiversité et d'Ecologie marine et continentale).

Morphological Comparisons: Measurements. Snout to vent length (SVL) - measured from tip of snout to caudal edge of anal scales; axilla to groin distance-measured from middle of base of forelimb to middle of base of hindlimb; forelimb to snout lengthmeasured from tip of snout to middle of base of forelimb; hindlimb length-from middle of base of hindlimb to tip of fourth toe including nail; tail length-measured from caudal edge of anal scales to tip of tail on complete original tails only, but estimated here as both specimens had regrown tails. Body measurements (axilla to groin, forelimb to snout, hindlimb, and tail lengths) are for both specimens, and are expressed as a percentage of snout-to-vent length in the taxon account. Sex of the holotype as female was determined by the presence of eggs, and the paratype as male by the presence of testes.

Scalation. Midbody scale rows (MBR)number of longitudinal scale rows around body counted midway between axilla and groin; dorsal scale rows (DSR)-number of scales in a row from first scale posterior to parietal scale to last scale at level of vent opening; fourth finger (FFS) and toe (FTS) scales-number of dorsal scales on fourth digit of the manus and pes, distal scale contains claw, basal scale broadly contacts adjacent basal scale of third finger or toe; fourth finger (FFL) and toe (FTL) lamellaenumber of ventral scales on fourth digit of the manus and pes, distal scale contains claw, basal scale is last largely undivided scale at, or proximal to, a point level with intersection of third and fourth digits. Bilateral scalation characters were scored on both sides and the mean value used.

The description of the new species presented here is based on two specimens, the holotype and paratype, with variation in coloration supplemented by images of live individuals not vouchered. Allocation of the new species to a new genus is based on morphological criteria, with comparisons made to other genera in the Eugongylus group of skinks, a morphologically based lineage as defined by Greer (1979) for which monophyly has since been independently corroborated in subsequent genetic studies (Honda et al. 2000). Tissue samples were not available to generate DNA sequence data for inclusion of the new species into the framework of phylogenetic relationships for New Caledonian skinks derived from molecular data (Smith et al. 2007). This study identified the endemic New Caledonian skink genera as part of a regionally discreet monophyletic evolutionary lineage, the Tasmantis group of skinks, one that also includes the New Zealand skinks and the endemic species found 
on Lord Howe Island and the Norfolk Island (s) group in the southwest Pacific Ocean. Monophyly of the Tasmantis group was supported in a later genetic study, by Chapple et al. (2009), which focused on the New Zealand skink fauna. However, the study by Smith et al. (2007) and a later analyses of molecular data for the New Caledonian skinks by Ineich et al. (2014) have both supported the robustness of genera proposed primarily on morphological criteria to accommodate the diversity of evolutionary lineages within the endemic New Caledonia skink fauna. The only exception to this was Lioscincus, which was resurrected from synonymy by Bauer and Sadlier (1993) to accommodate a suite of residual New Caledonian taxa formerly included in Leiolopisma and explicitly identified as polyphyletic (Sadlier et al. 1998), a concept later supported in the molecular phylogeny presented by Smith et al. (2007). Subsequently, Sadlier et al. (2015) used a combination of morphological and genetic information to delineate four monophyletic genera from among its constituent species. The only member of the New Caledonian lizard fauna for which significant phylogenetic uncertainty remains is Geoscincus haraldmeieri, an unusual species known only from the two individuals included in the original description in 1976 (Böhme 1976; Sadlier 1986).

\section{SYSTEMATICS}

The following suite of morphological characteristics (apomorphies*) identify the new species of lizard described here from the Île des Pins as a member of the Eugongylus group of skinks as defined by Greer (1979): parietal scales meeting behind the interparietal*; parietal bordered along its posterior edge by an upper secondary temporal and transversely enlarged nuchal scale*; medial preanal scales more or less subequal in size to and overlapped by more lateral preanals; and the scales on the dorsal surface of the fourth toe are in a single row throughout the length of the digit. The number of premaxiliary teeth and other aspects of osteology have not been assessed on the limited number of specimens from which the species is known.
Kuniesaurus gen. nov. Sadlier, Deuss, and Bauer

Type species: Kuniesaurus albiauris n. sp.

Diagnosis: Kuniesaurus can be distinguished from all other genera in the Eugongylus group of Greer (1979) by the following combination of derived character states (apomorphies) as defined by Sadlier (2010): supranasal scale or postnasal suture absent; anterior loreal reduced in size and present as a semilunar scale positioned on the posterodorsal margin of the nasal and failing to contact the upper labials; subocular scale row complete; a reduction in the number of upper labial scales (to six) and lower labial scales (to five); frontoparietal scales fused; lower eyelid with an obvious, centrally located semitransparent disc; ear lobules barely distinguishable from blunt conical scales around upper, lower, and posterior edges of ear opening; diminutive size (adults $<50 \mathrm{~mm}$ SVL).

The New Caledonian taxa Celatiscincus and Marmorosphax share the greatest number of derived character states with Kuniesaurus, namely the lack of a supranasal scale or postnasal suture; anterior loreal significantly reduced in size (failing to contact the upper labials in Marmorosphax); in having a complete subocular row of scales; frontoparietal scales fused; lower eyelid with an obvious, centrally located semitransparent disc; and a large round ear opening with the lobules barely distinguishable from adjacent scales. Kuniesaurus has a reduced number of upper labial and lower labial scales, derived character states not present in either Celatiscincus or Marmorosphax, both of which have the modal plesiomorphic state (upper labials seven; lower labials six). Both Celatiscincus and Marmorosphax have keeled body scales, a trait considered apomorphic within the New Caledonian skink radiation, whereas Kuniesaurus has smooth body scales, the state considered plesiomorphic within the New Caledonian skink radiation. Celatiscincus and Marmorosphax also each possess additional apomorphies not shared with Kuniesaurus. In Celatiscincus the parietal scales are each bordered by a single enlarged temporal scale and divided nuchal scale into two (sometimes three) scales that are transversely enlarged but equal in 

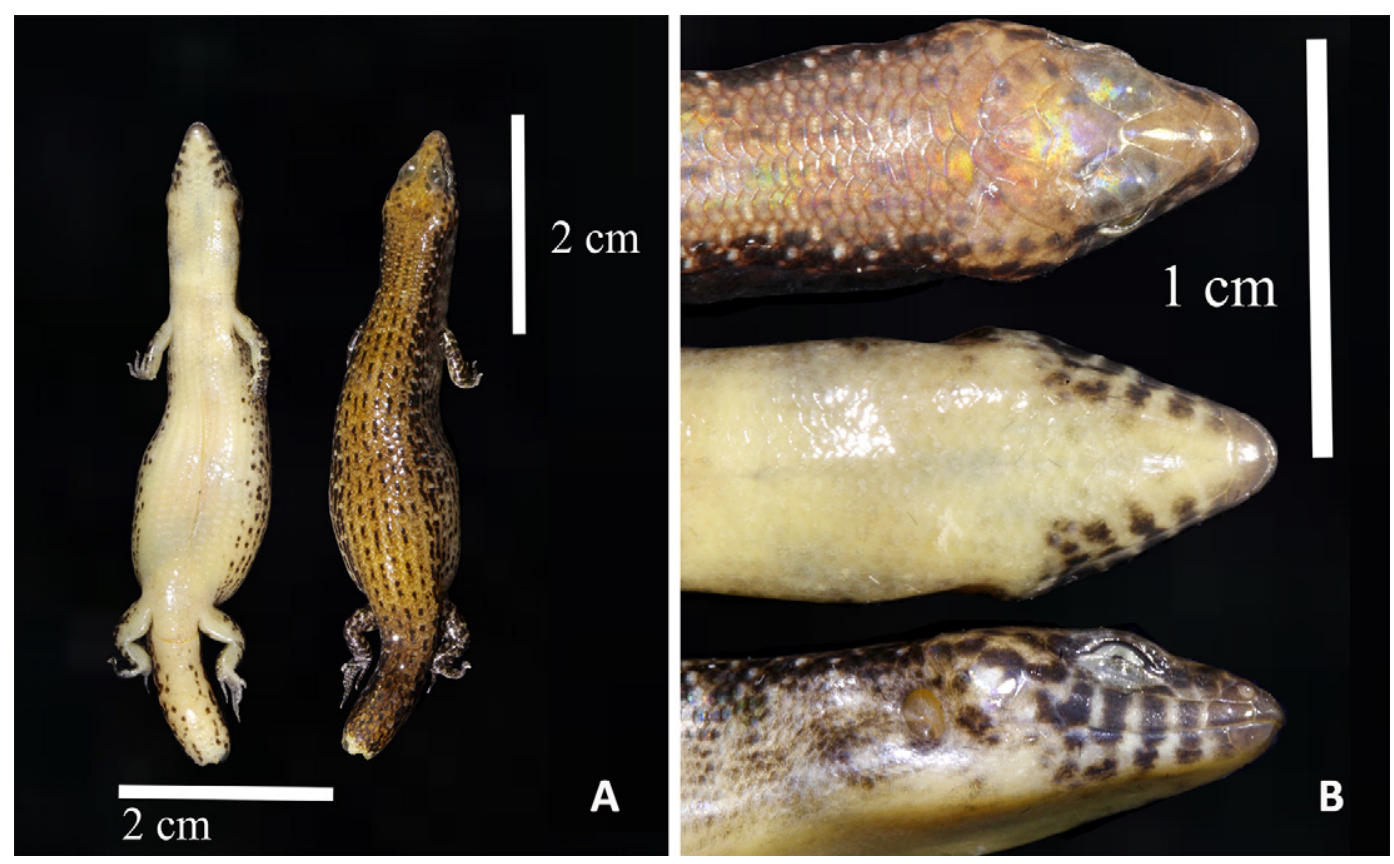

Figure 1. Adult female holotype of Kuniesaurus albiauris n. sp. (MNHN-RA-2017.0101) showing the darkly streaked dorsal and lateral color pattern of the body $(A)$ and side of head $(B)$.

size to the adjacent body scales (versus the plesiomorphic condition of the parietals each bordered by a single enlarged temporal scale and transversely enlarged nuchal scale in Kuniesaurus), and in Marmorosphax the division of the third pair of chinshields such that the scales contacting the lower labials are separated from each other by an intervening row of five scales (versus the plesiomorphic condition of the enlarged third pair of chinshields separated from each other by three intervening scales in Kuniesaurus).

Kuniesaurus has an egg-laying mode of reproduction (oviparous the plesiomorphic condition), a trait that further distinguishes it from Marmorosphax, which is live-bearing (ovoviviparous the apomorphic condition), at least for those species in which the mode of reproduction has been determined.

Etymology: The name is derived from Kunié, given to the main island of the Île des Pins by its indigenous Kanak population, and saurus, the New Latin form of the Greek sauros =lizard. The gender is masculine.
Recognized species: Kuniesaurus albiauris $\mathrm{n}$. $\mathrm{sp.}$

Kuniesaurus albiauris Sadlier, Deuss, Bauer, and Jourdan n. sp.

Isle of Pines white eared skink/Scinque à oreilles blanches de l'Île des Pins.

Figures 1-5

Type Material: Holotype MNHN-RA2017.0101 New Caledonia, Île des Pins $22.59748^{\circ} \mathrm{S} 167.52472^{\circ} \mathrm{E}$ (Figure 1 and Figure 2). Paratype MNHN-RA-2017.0102 New Caledonia, Ile des Pins $22.59427^{\circ} \mathrm{S}$ $167.52453^{\circ} \mathrm{E}$-both holotype and paratype collected by Matthias Deuss, 20 December 2015.

Etymology: The species epithet albiauris is a noun in apposition and is derived from the Latin albus (white) and auris (ear) and is used in reference to the prominent white spot in the region of the lower secondary temporal giving the appearance of having white ears.

Diagnosis: see generic diagnosis. 

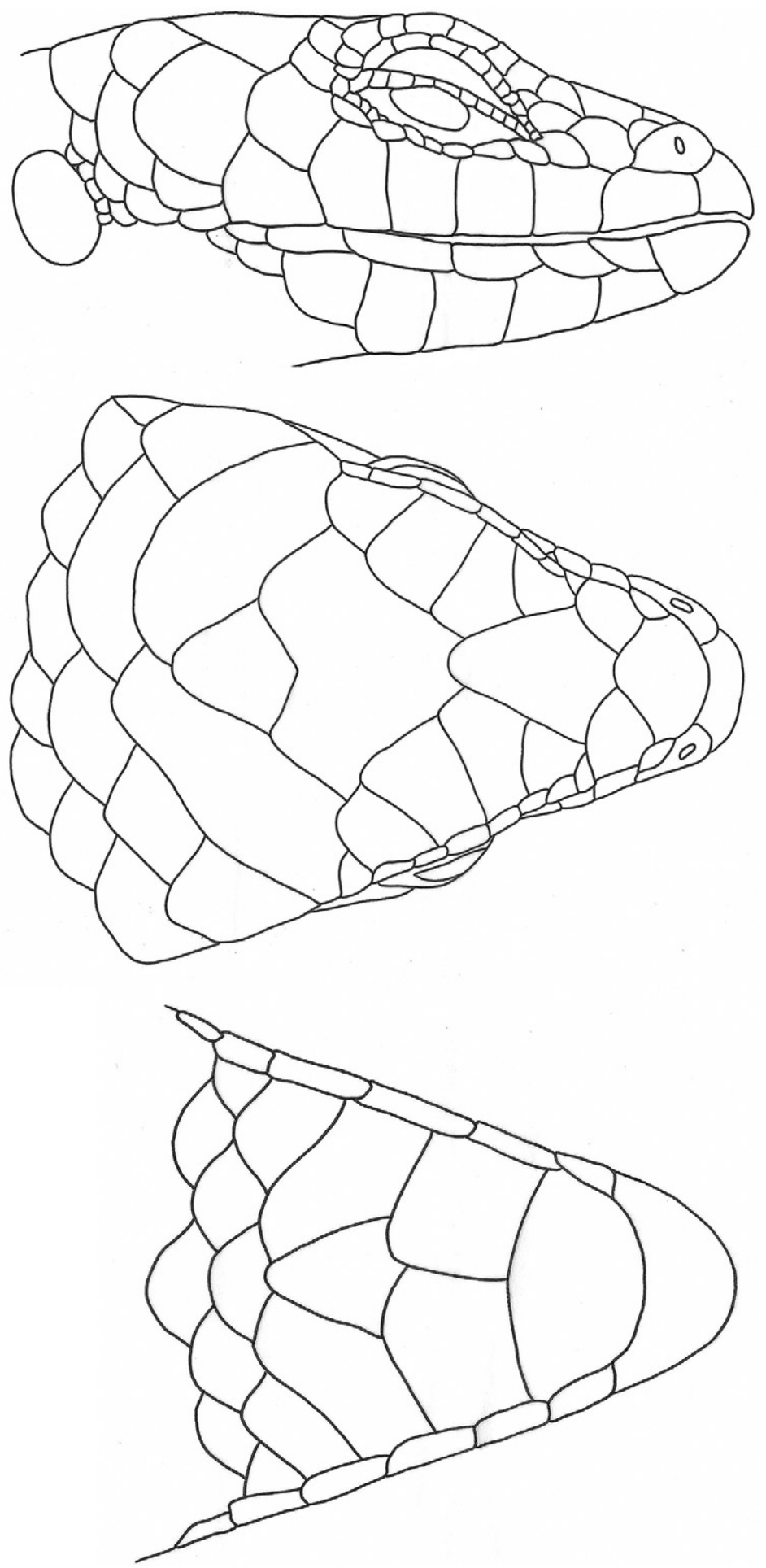

FIGURE 2. Head scalation of adult female holotype of Kuniesaurus albiauris n. sp. (MNHN-RA-2017.0101), showing the lateral (upper), dorsal (middle), and ventral (lower) aspects. 


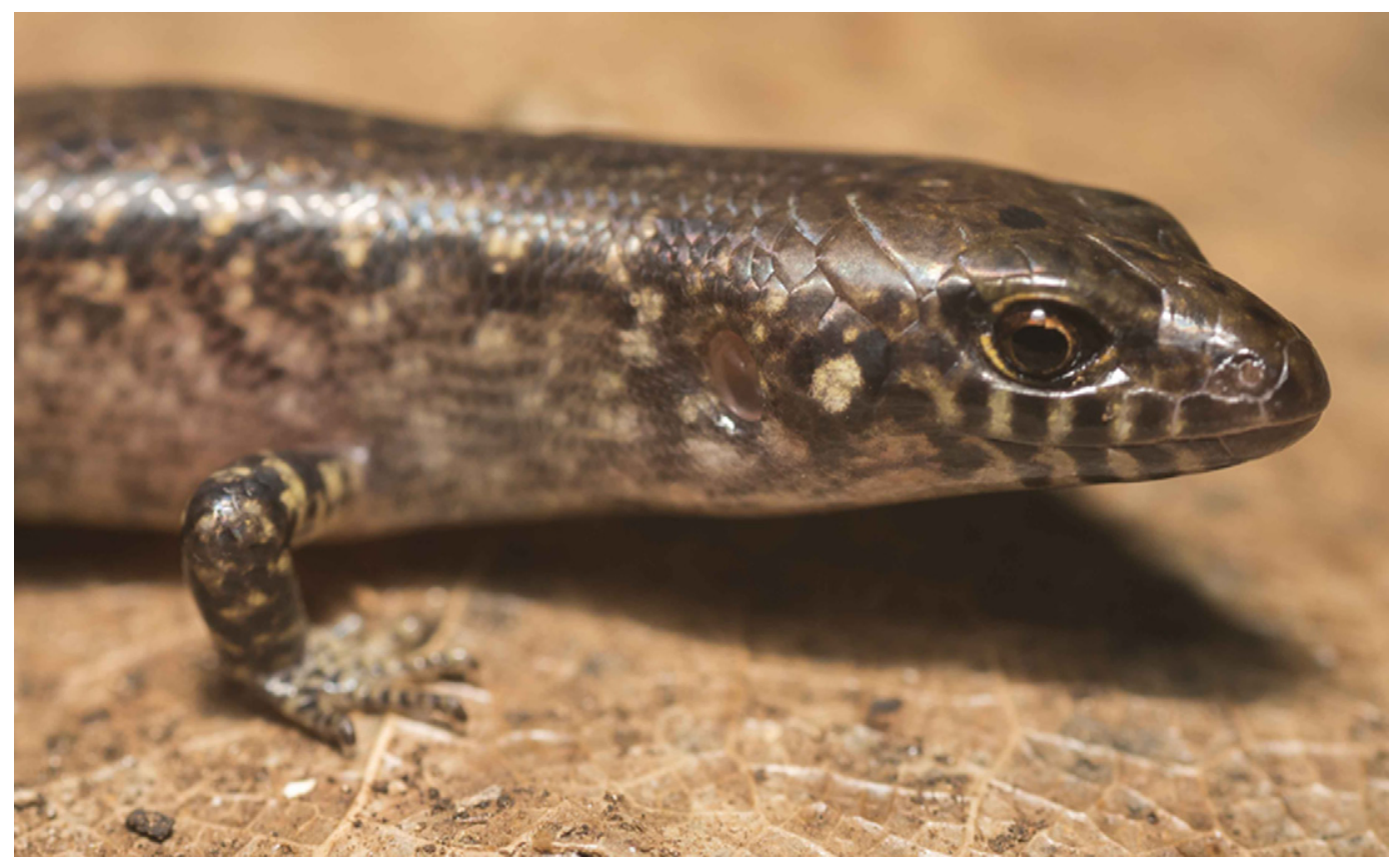

FiguRE 3. Adult male paratype of Kuniesaurus albiauris n. sp. in life.
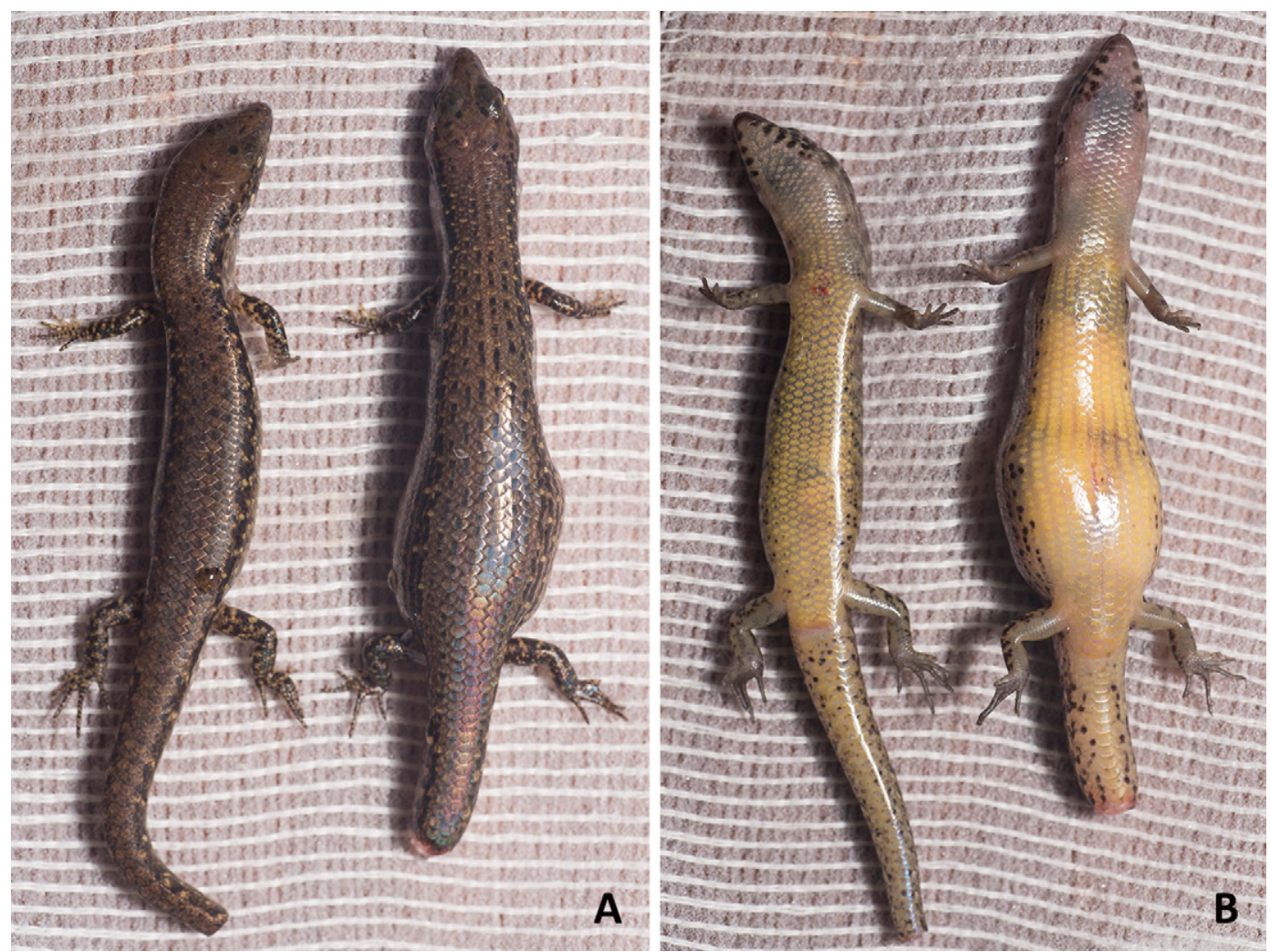

FIgURE 4. Dorsal $(A)$ and ventral $(B)$ surface of adult female holotype (MNHN-RA-2017.0101 -- right) and adult male paratype (MNHN-RA-2017.0102 - left) Kuniesaurus albiauris n. sp. prior to preservation, note the undersurface of the head and neck are pale, graey in color, whereas the undersurface of body and tail $(B)$ has a yellow flush posterior of the forelimb. 

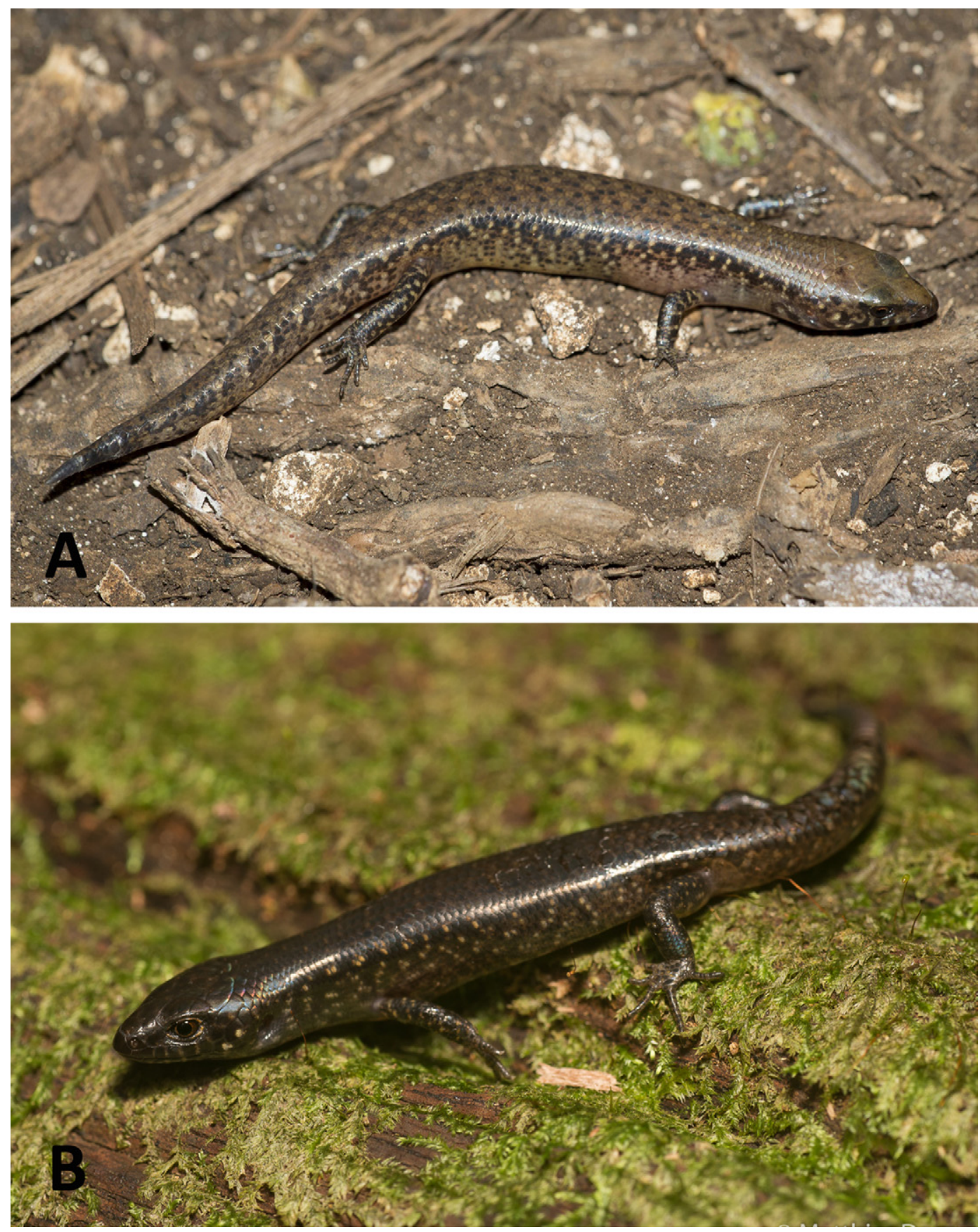

Figure 5. Adult Kuniesaurus albiauris n. sp. (A) (sex unknown) from the type locality, note the distinctive white temporal spot on the side of the head, and a juvenile $(B)$ (sex unknown) from the same area. 
Description: Scalation and coloration is based on the single adult female holotype and adult male paratype.

Measurements. Snout to vent length (SVL) $46.0 \mathrm{~mm}$ (holotype) $40.5 \mathrm{~mm}$ (paratype); distance from axilla to groin $54.3 \%$ of SVL; distance from forelimb to snout $39.5 \%-40.2 \%$ of SVL; hindlimblength $29.3 \%-33.3 \%$ ofSVL; tail lost in both individuals but from images of live specimens would appear to be approximately equal in length to body $\sim 100 \%$ SVL.

Scalation. Prefrontals large, narrowly to moderately separated; frontoparietals fused; interparietal distinct; parietals meet behind interparietal, parietals each bordered by a transversely elongate upper secondary temporal scale and nuchal; primary temporal single; upper secondary temporal single; lower secondary temporal single; tertiary temporals two; postlabials scales two; nasal scales moderately large, moderately/widely separated; supraciliaries seven; upper labials six with the fourth subocular and separated from contact with the lower eyelid by a complete row of subocular scales; lower labials five, first two contacting postmental; enlarged chinshields three, members of first pair in broad contact, members of second pair separated by one scale, members of third pair by three scales. Lower eyelid with an obvious, centrally located, semitransparent disc. Ear opening large and without obviously enlarged lobules anteriorly. Body scales smooth. Midbody scale rows 32; dorsal scale rows 53-56; scales on top of fourth finger $6-8(\bar{x}=7)$; lamellae beneath fourth finger $12-14(\bar{x}=11.6)$; scales on top of fourth toe 11; transversely enlarged lamellae beneath fourth toe $20-23(\bar{x}=21.25)$, with a series of several granular scales basally.

Coloration. Adult female (Figure 1 and Figure $4 A$ right and $4 B$ right): Dorsal surface of the body brown with a series of dark broken longitudinal stripes down the body from the nape to past the level of the hindlimbs. Each stripe composed of a series of prominent dark streaks, each of which runs down the center of the dorsal scale (often failing to reach the anterior and/or posterior edge of the scale) and can be absent from each second or third scale. Dorsal surface of head mid-brown (similar to body) with dark blotches on most major head shields and a concentration of dark markings on the supraciliary shields. Lateral surface of the body with an underlying background color that grades from brown uppermost (an extension of the dorsal color) through to gray approaching the ventrolateral surface, extensively marked with a pattern of dark longitudinal streaks (similar to the dorsal surface) and to a lesser extent scattered pale spots. Width of the dark streaks variably dominates each scale, but is particularly intense on the upper lateral surface where it approaches the dorsal surface, resulting in most scales in the dorsolateral region having a dark median streak. Paler areas of of the posterior half of the lateral surface of the body with a dull yellow flush overall in life (similar to adjoining ventral surface), including the pale spots of the upper lateral surface of the body, neck and head, whereas the pale mid and lower lateral areas of the anterior part of the body either side of the forelimb are gray to pinkish-gray in life. Side of head with an underlying background color of light brown to gray similar to the lateral surface of the body, but dark overall by virtue of the head scales being dominated by extensive dark markings, and with a pattern of pale spots and blotches to the labial and temporal scales, these with a faint yellow flush in life except for the large and prominent spot on the lower secondary temporal scale, which is white. The undersurface of the head and neck is pale gray in life, and with large dark blotches present on the outer margin of the postmental scale and the chinshields, where they contact the adjoining dark blotches of the lower labials. Undersurface of body and tail is pale, in life with a yellow flush posterior of the forelimb, and the tail has a row of dark spots on the underside along the ventrolateral margin.

Adult male (Figure 3 and Figure $4 A$ left and $4 B$ left): Dorsal surface of the body brown with occasional scattered dark markings down the center of the dorsal scales. Lateral surface of the body with an underlying background color of cream to gray with a pattern of irregularly distributed dark longitudinal streaks uppermost, becoming more diffuse over the remainder of the side of the body, but also with scattered dark blotches. Dorsal 
surface of head brown (similar to body) with only a few dark markings, and the side of head with an underlying background color of gray but with each scale dominated by extensive dark markings, and the same pattern of pale spots and blotches to the labial and temporal scales as in the adult female, dull cream to faint yellow in life except for the large and prominent pale spot near the lower secondary temporal scale, which is white. The undersurface of body, neck, and head similar to the adult female (above), also with a yellow flush on the abdomen posterior of the forelimb and along the underside of the tail (Figure $4 B$ left).

Images of other live adult individuals from Île des Pins (sex unknown) also show these to have a yellow flush to the abdomen posterior of the forelimb and along the underside of the tail, a large and prominent white spot in the region of the lower secondary temporal (Figure $5 A$ ), and a dull golden yellow color on the posterior part of the rim of the lower eyelid, and to a lesser extent the posterior part of the upper eyelid.

Juveniles (Figure 5B): The only juvenile specimen photographed (non-vouchered and of undetermined sex) was very dark, with very faint yellow streaks on jaws, almost no color transition between dorsum and sides, more conspicuous dark markings on ventral side, including between jaws, forelimbs and hindlimbs, and the pale yellow area on ventral side extended frontward further than in adults.

Distribution and Habitat: Very little is known of the natural history of this species. The only known area of occurrence is in humid forest on calcareous soils in the northeastern part of mainland Île des Pins (Figure 6). Here

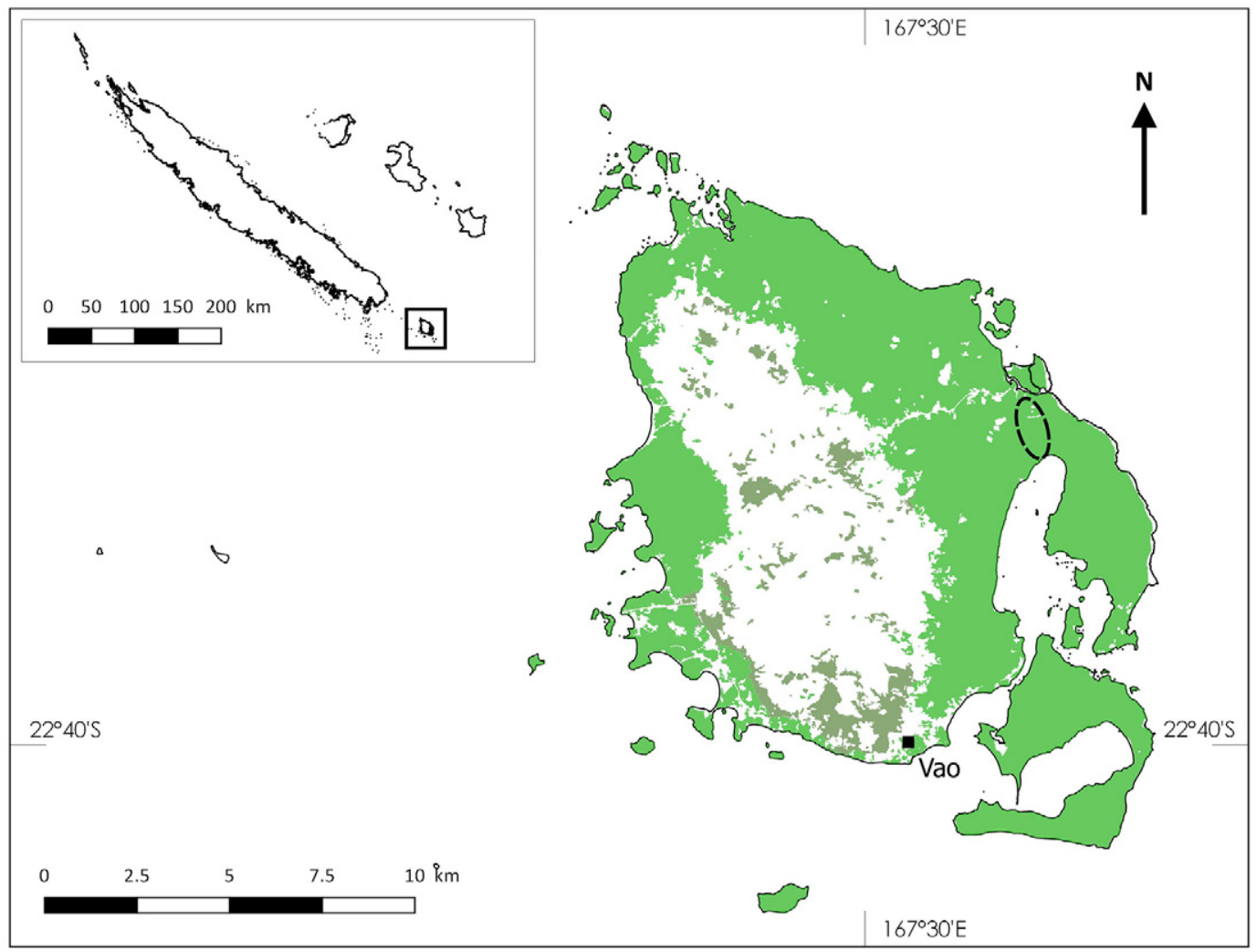

FIgURE 6. Location of the type locality for Kuniesaurus albiauris n. sp. (area within dashed lined) on the Île des Pins. Bright green areas represent forests on coralline soil, whereas dark green areas represent forests on ultramafic soils. Source of data: Gouvernement de la Nouvelle-Calédonie. Figured by Matthias Deuss. 


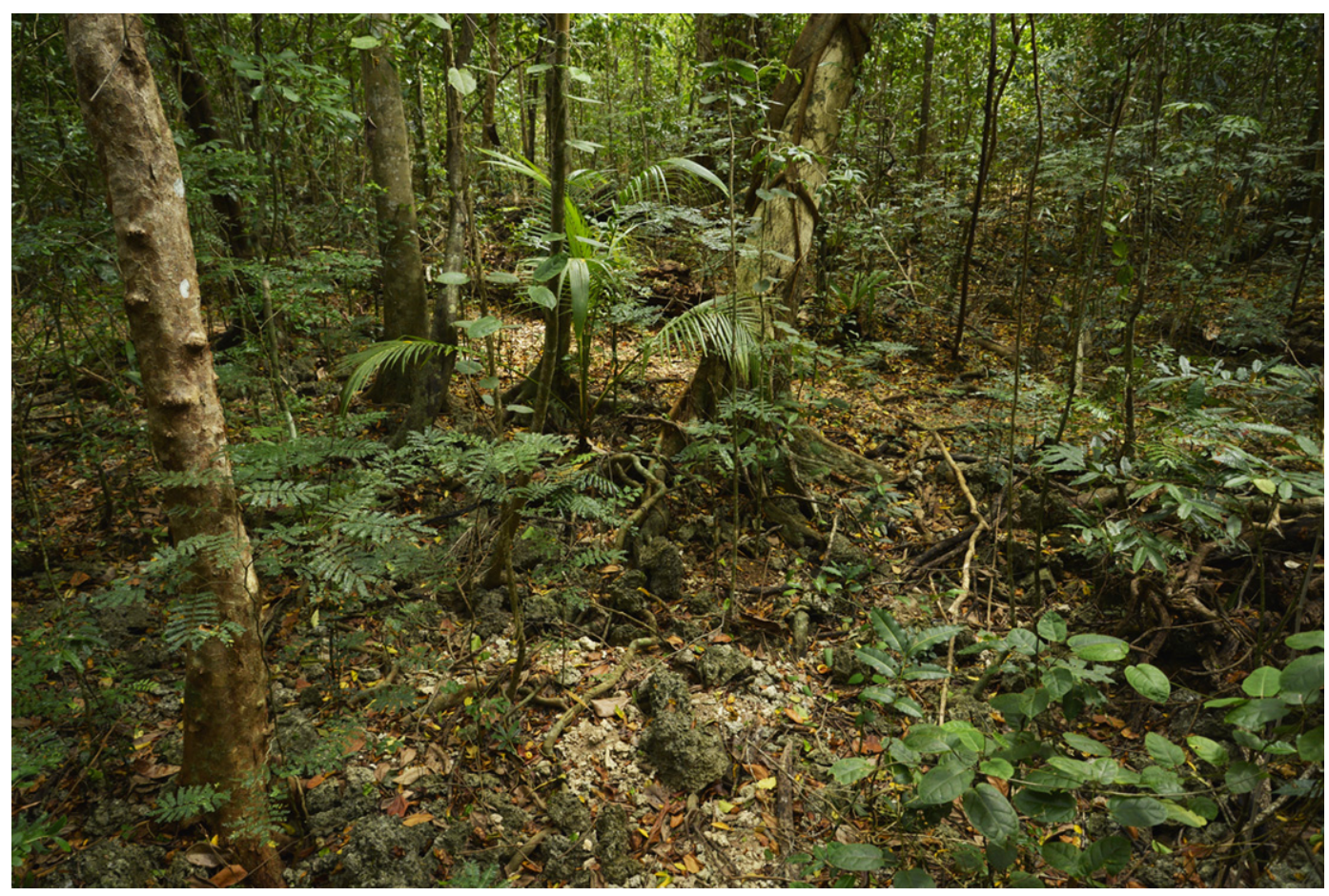

FIGURE 7. Habitat from which Kuniesaurus albiauris n. sp. was collected in humid forest on coralline soils on the Île des Pins.

the species was frequently encountered sheltering under rocks and decaying wood along a track (Figure 7), and when uncovered quickly escaped beneath the litter; it has not been observed active on the surface. This pattern of behavior is similar to the species of Marmorosphax which are absent from Île des Pins, and Kuniesaurus albiauris n. sp. may fill a similar ecological niche. At this location it is sympatric with five other small species of skink. Of these, Nannoscincus sp. are almost exclusively fossorial in habits and Sigaloseps sp. primarily fossorial but with periods of surface activity, Celatiscincus euryotis appears to be a litter dwelling species with frequent periods of surface activity $(\mathrm{HJ}$ and MD pers. obs.), and the species Caledoniscincus bodoi and Caledoniscincus atropunctatus are primarily surface active litter skinks and both are common at the type locality. Based on the few surveys carried out on this track, Kuniesaurus seems restricted to the uplifted coralline "plateau" (like Celatiscincus euryotis) where the forest is less disturbed and condi- tions are more humid. It has not been recorded from the adjacent, near sea level, disturbed littoral forest, which is dominated by Cocos nucifera and Araucaria columnaris. Kuniesaurus has been encountered in three different periods: June, October, and December during cloudy to sunny and hot weather, whereas sympatric Sigaloseps sp. was not found in June in a three-hour search.

Reproductive biology: This species is oviparous, the adult female holotype collected in December contained three large shelled eggs. One juvenile was observed in June 2016.

Conservation status: Kuniesaurus albiauris n. sp. has a very restricted known area of occupancy. What is known of its distribution on the island indicates it occupies the less disturbed forest on uplifted coralline surfaces on the east side of the island. The area of humid forest on calcareous soils on the Île des Pins is estimated at around $75 \mathrm{~km}^{2}$, approximately half the surface of the island (not including Ile Kotomo), although the actual 
extent of suitable forest habitat is likely to be less, given some areas of forest on the west side of the island are likely to be disturbed by human activities and represent areas of regrowth forest/secondary forest.

The most significant threats to Kuniesaurus albiauris $\mathrm{n}$. sp. come from the presence of invasive species, primarily rodents (Pacific Rat and Ship Rat), feral cats, and invasive ants. The negative impact of rats on island lizard populations has been well documented (Whitaker 1973; Monks et al. 2014), with their presence clearly suppressing potential lizard population densities (Thibault et al. 2017). A negative impact on lizard populations by the Little Red Fire Ant (LFA) Wasmannia auropunctata has also been identified, with studies in dry forest habitat in New Caledonia reporting a lower abundance of several lizard species in invaded areas (Jourdan et al. 2001), and it is considered to be a major threat islandwide. Similarly, the presence of the introduced Yellow Crazy Ant (YCA) Anoplolepis gracilipes could also present a threat. Booms in Crazy Ant populations have been identified as a likely contributing factor in the decline of some lizard species on Christmas Island in the Indian Ocean (Smith et al. 2012). Both the LFA and YCA are reported from coastal limestone forests on Île des Pins. At this time the YCA is more established in the forest on the west coast of the main island, whereas LFA is actively spreading on the east coast, and has been detected in close proximity to the area of the known population of Kuniesaurus (Jourdan et al. 2011, 2012, 2013). The spread of the LFA is a major concern for long-term survival of Kuniesaurus given it is a cryptic species that inhabits litter, where the LFA is known to establish nests. The threats posed by these ants come from the physical displacement of lizards from sheltering and foraging sites by the presence of large numbers of ants during boom periods, and indirectly from the loss of potential invertebrate prey that constitute part of the lizards diet, as a result of declines accompanying the spread of the invasive ants (Jourdan et al. 2001). The negative impact of feral cats on the lizard fauna of New Caledonia has recently been recognized. Palmas et al. (2017) illustrated a previously unreported high level of cat predation on native skinks, especially the ground dwelling species Marmorosphax tricolor.

The species restricted extent of occurrence, in combination with the threats posed by the presence of rodents and the occurrence of the invasive ant Wasmannia auropunctata near its only known site, place Kuniesaurus albiauris $\mathrm{n}$. sp. at high level of risk, satisfying the criteria to be ranked as Critically Endangered under the IUCN Red List classification system (IUCN 2017): it has a its extent of occurrence is estimated to be less than $100 \mathrm{~km}^{2}$ (criteria B1); it is known only from one location (criteria B1a); and by virtue of the impact of introduced predators it has an inferred decline in area, occurrence, occupancy and extent and/or quality of habitat (criteria B1b i-iii). The population status of the species at the type locality needs to be investigated, as does its possible occurrence in suitable habitat elsewhere on the Île des Pins and its surrounding islands.

\section{DISCUSSION}

The rediscovery of the giant skink Phoboscincus bocourti in 2003 (Ineich 2009) on islets surrounding the Île des Pins, almost 150 years after it was initially discovered, is one among the following factors, all indicating that the Ile des Pins and its associated islets have a richer and more complex lizard fauna than previously thought: the formal recognition of the giant gecko Rhacodactylus trachycephalus as an island endemic (Bauer, Jackman et al. 2012), the recognition of the skinks Celatiscincus euryotis (Sadlier, Smith et al. 2006) and Caledoniscincus bodoi (Sadlier, et al. in prep) as regional island endemics, and now the discovery of a monotypic genus of skink endemic to the region and two other species of skink not previously recorded (an undetermined species of Sigaloseps and Nannoscincus).

Of particular interest is the composition of the lizard fauna present on the Île des Pins and its satellite islands with respect to that of the southern Grande Terre, the region south of the Thio Valley dominated by the southern ultramafic bioregion (Figure 8), as well as the inference that can be drawn regarding their 


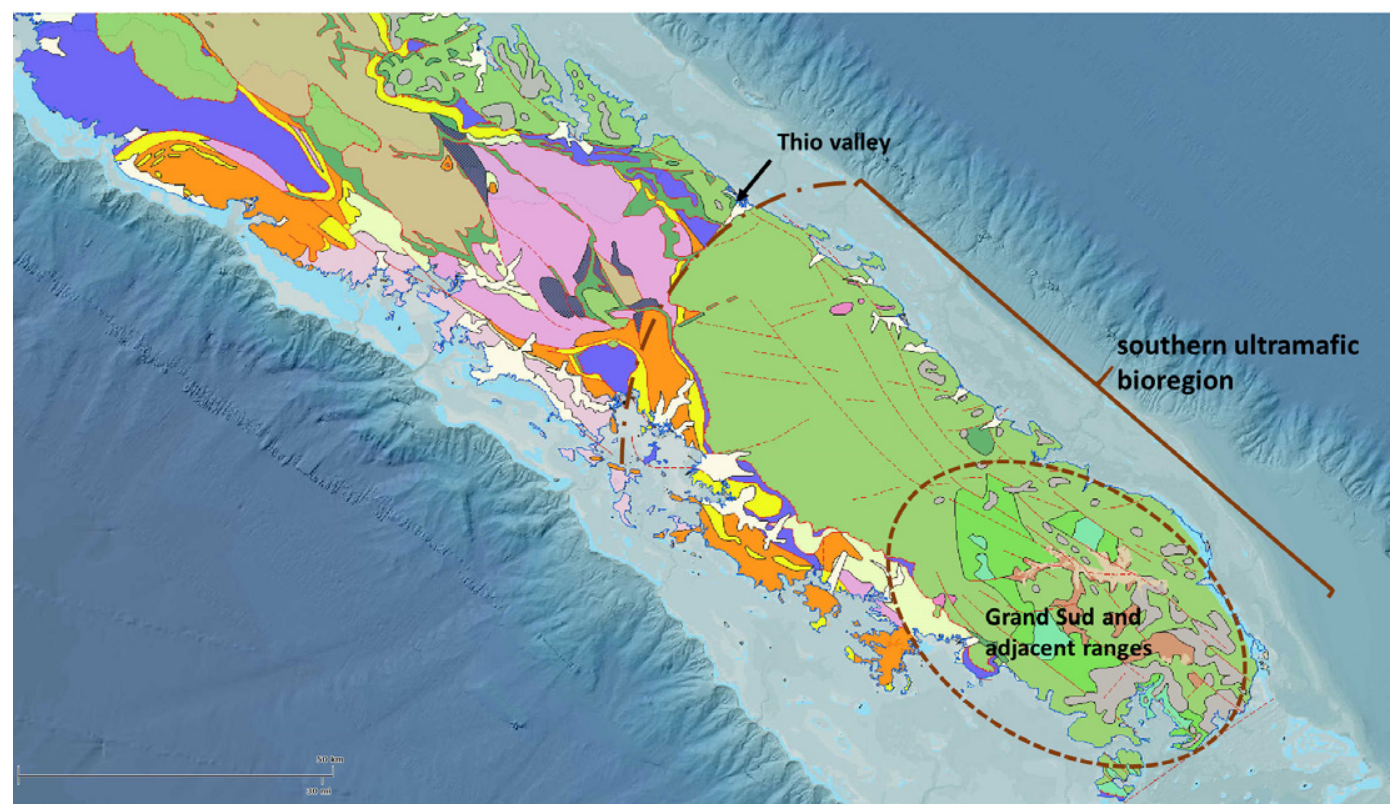

FIGURE 8. The area of ultramafic surfaces (light green) covered by the southern ultramafic bioregion in southern New Caledonia, showing the northern limits at the Thio valley (dash-dot-dash brown line) and the area in the south referred to as the Grand Sud, a sub-region within which a number of southern ultramafic endemic species appear to be restricted. Source of data: DIMENC (direction de l'industrie, des mines et de l'énergie), Gouvernement de la NouvelleCalédonie, 2012.

historical distribution and the nature of past connectivity between the two areas.

The occurrence on both the Île des Pins and in southern New Caledonia of lizard species that lack obvious water-crossing capabilities, such as the geckos Correlophus ciliatus, Mniarogekko chahoua, and Eurydactylodes vieillardi, suggests that land connection sufficient for dispersal of such lizards existed historically between the two regions, and the presence of two lineages each of which has highly divergent sister taxa consisting of a taxon endemic to the Île des Pins with an evolutionary counterpart on Grande Terre, further suggests that historically older patterns of connection and isolation between the two regions also existed prior to those of the Pleistocene period identified by Pelletier (2007). The high level of genetic differentiation between the regional endemic Rhacodactylus trachycephalus and its sister species $R$. trachyrbynchus (Bauer, Jackman et al. 2012) indicates that they have long been separated from one another. A similar evolutionary scenario is seen in the insular endemic Celatiscincus euryotis and its only congener, C. similis from the northern Grande Terre (Sadlier, Smith et al. 2006). The morphological distinctiveness of Kuniesaurus albiauris $\mathrm{n}$. sp., with no apparent obvious close relationship to any known genus, hints at an even deeper history of connectivity and isolation between the Ile des Pins and southern New Caledonia.

The southern Grande Terre has a rich lizard fauna of 43 species endemic to New Caledonia. Extensive field research in this region over the past 10 to 15 years has greatly increased our knowledge of the distribution and habitat preferences of many species in this region, and resulted in the discovery of a number of new taxa (Bauer et al. 2008; Bauer, Sadlier et al. 2012; Sadlier, Bauer et al. 2006; Sadlier et al. 2013, 2014a, 2014b, 2014c). Over half of the lizard species recorded are regional endemics and most are restricted to habitats on ultramafic surfaces, identifying it as a significant bioregion for lizards, with the 
remainder tending to be more widespread in distribution and also occurring on habitats on non-ultramafic surfaces (Table 1). Of the 17 native species now recorded from the Île des Pins (excluding the as yet undetermined species of Sigaloseps and Nannoscincus), 12 also occur on the southern Grande Terre (some more widely distributed); the remaining 5, Rhacodactylus trachycephalus, Caledoniscincus bodoi, Celatiscincus euryotis, Kuniesaurus albiauris n. sp., and Phoboscincus bocourti, are endemic to the island region (Table 1). Given the increase in knowledge of the lizard fauna of both the southern Grande Terre and the Île des Pins, we take the opportunity to review the affinities of the species found in both regions.

Seven species of diplodactylid geckos are recorded as native to the Île des Pins (Geneva et al. 2013), including four species of giant gecko (Correlophus ciliatus, Mniarogekko chaboua, Rhacodactylus leachianus, and Rhacodactylus trachycephalus), two species of Bavayia (Bavayia robusta and Bavayia sauvagii), and one Chameleon Gecko (Eurydactylodes vieillardi). All except one, the giant gecko Rhacodactylus trachycephalus, also occur on Grande Terre (Table 1). Three of the giant geckos recorded from the main island of the Ille des Pins, Correlophus ciliatus, Mniarogekko chaboua, and Rhacodactylus leachianus, also have broad (but patchy in ciliatus and chaboua) distributions on the Grande Terre in mostly forested habitats on both ultramafic and nonultramafic surfaces. All three have been recorded in the southern Grande Terre, primarily in humid forest on the southern ultramafic ranges, but Rhacodactylus leachianus also occurs in other forest habitats, including coastal forests and islets off the east coast. The three other gecko species, Bavayia robusta, Bavayia sauvagii, and Eurydactylodes vieillardi, are also found on both the Île des Pins and the Grande Terre. The complexities of the systematics of both Bavayia robusta and Bavayia sauvagii are still under review but the taxa ultimately to be recognized under these names will be restricted to southern Grande Terre including the Île des Pins. Across their range they occupy a range of habitats on both ultramafic (robusta humid forest; sauvagii humid forest, maquis forest and maquis shrubland) and nonultramafic surfaces (robusta coastal forest, sclerophyll forest and mangroves; sauvagii sclerophyll forest).

Six of the diplodactylid geckos recorded from southern New Caledonia have not been recorded on the Île des Pins: five of these are endemic to the southern ultramafic bioregion, and one, Rhacodactylus auriculatus, is restricted to ultramafic surfaces of both southern and northern Grande Terre. Two of these (Bavayia geitiana and Eurydactylodes symmetricus) are widespread in the bioregion, one (Correlophus sarasinorum) is widespread in the south of the bioregion, while the remaining two have more restricted distributions, one (Bavayia nubila) to the interior ranges of the southern ultramafic region and one (Bavayia goroensis) to the ultramafic plateau in the far south of the bioregion. While the two range-restricted species likely represent localized endemics, the absence of the other four species from the Île des Pins is less readily explained, given their presence in ultramafic habitats on the adjacent southern Grande Terre.

The composition of the skink fauna of southern Grande Terre relative to that recorded from the Île des Pins is even more complex. An extensive suite comprising 28 species of skink is known to occur in the southern Grande Terre. Some species, as currently conceived, are taxa with widespread distributions on the Grande Terre $(n=12)$, but the majority (16) are taxa endemic to the southern ultramafic bioregion. Some of the skink taxa endemic to the southern ultramafic region have restricted distributions, either in the ranges of the interior (8) and/or the far south - in the area known as the Grand Sud (5) - but some are also widespread (4). With two possible exceptions (discussed below), none of the skink taxa endemic to the southern ultramafic bioregion are found on the Île des Pins.

Aside from the five island endemics (including Kuniesaurus albiauris n. sp.) the skinks recorded from the Île des Pins also includes six taxa that are widely distributed on Grande Terre. Two additional species, one in the genus Sigaloseps and one in the genus Nannoscincus, are also known to occur on the Île des Pins, but the identity of these and whether they are con- 
TABLE 1

Skinks and geckos recorded from southern Grande Terre and Île des Pins showing those with distributions that extend across the Grande Terre (GT), those with distributions limited to the southern Grande Terre but recorded from both ultramafic and non-ultramafic surfaces (SGT); those restricted to ultramafic surfaces of the southern ultramafic bioregion (SUB); and taxa recorded from the Ile des Pins (IoP). A general assessment of the species distribution is also given.

\begin{tabular}{|c|c|c|c|c|}
\hline Diplodactylidae & Bavayia geitaina & SUB & & Widespread across SUB \\
\hline Diplodactylidae & Bavayia goroensis & SUB & & Restricted to south of SUB \\
\hline Diplodactylidae & Bavayia nubila & SUB & & Restricted to ranges of SUB \\
\hline Diplodactylidae & Bavayia robusta & SGT & IoP & Widespread across SGT $+\mathrm{IoP}$ \\
\hline Diplodactylidae & Bavayia sauvagii & SGT & IoP & Widespread across SGT $+\mathrm{IoP}$ \\
\hline Diplodactylidae & Bavayia septuiclavis & SUB & & Widespread across SUB \\
\hline Diplodactylidae & Correlophus ciliatus & GT & IoP & Widespread across GT $+\mathrm{IoP}$ \\
\hline Diplodactylidae & Correlophus sarasinorum & SUB & & Restricted to south of SUB \\
\hline Diplodactylidae & Eurydactylodes symmetricus & SUB & & Widespread across SUB \\
\hline Diplodactylidae & Eurydactylodes vieillardi & GT & IoP & Widespread across GT + IoP \\
\hline Diplodactylidae & Rhacodactylus auriculatus & GT & & Widespread across GT \\
\hline Diplodactylidae & Rhacodactylus trachycephalus & & IoP & Restricted to IoP \\
\hline Diplodactylidae & Rhacodactylus trachyrbynchus & GT & & Widespread across GT \\
\hline Diplodactylidae & Rhacodactylus leachianus & GT & IoP & Widespread across GT $+\mathrm{IoP}$ \\
\hline Diplodactylidae & Mniarogekko chaboua & GT & IoP & Widespread across GT + IoP? \\
\hline Scincidae & Caesoris novaecaledoniae & GT & & Widespread across GT \\
\hline Scincidae & Caledoniscincus atropunctatus & GT & IoP & Widespread across GT $+\mathrm{IoP}$ \\
\hline Scincidae & Caledoniscincus austrocaledonicus & GT & & Widespread across GT \\
\hline Scincidae & Caledoniscincus bodoi & & IoP & Restricted to IoP \\
\hline Scincidae & Caledoniscincus festivus & GT & & Widespread across GT \\
\hline Scincidae & Caledoniscincus haplorbinus & GT & IoP & Widespread across GT $+\mathrm{IoP}$ \\
\hline Scincidae & Caledoniscincus notialis & SUB & & Widespread across SUB \\
\hline Scincidae & Celatiscincus euryotis & & IoP & Restricted to IoP \\
\hline Scincidae & Cryptoblepharus novocaledonicus & GT & IoP & Widespread across GT $+\mathrm{IoP}$ \\
\hline Scincidae & Epibator greeri & GT & & Widespread ? across GT \\
\hline Scincidae & Epibator nigrofasciolatus & GT & IoP & Widespread across GT $+\mathrm{IoP}$ \\
\hline Scincidae & Graciliscincus shonae & SUB & & Restricted to south of SUB \\
\hline Scincidae & Kuniesaurus albiauris $\mathrm{n} . \mathrm{sp}$. & & IoP & Restricted to IoP \\
\hline Scincidae & Lacertoides pardalis & SUB & & Widespread ? across SUB \\
\hline Scincidae & Marmorosphax montana & SUB & & Restricted to ranges of SUB \\
\hline Scincidae & Marmorosphax tricolor & GT & & Widespread across GT \\
\hline Scincidae & Nannoscincus fuscus & SUB & & Restricted to ranges of SUB \\
\hline Scincidae & Nannoscincus garrulus & SUB & & Restricted to ranges of SUB \\
\hline Scincidae & Nannoscincus gracilis & GT & & Widespread across GT \\
\hline Scincidae & Nannoscincus mariei & SUB & & Restricted to south of SUB \\
\hline Scincidae & Phaeoscincus ouinensis & SUB & & Restricted to ranges of SUB \\
\hline Scincidae & Phasmasaurus tillieri & SUB & & Widespread across SUB \\
\hline Scincidae & Phoboscincus bocourti & & IoP & Restricted to IoP \\
\hline Scincidae & Phoboscincus garnieri & GT & IoP & Widespread across GT $+\mathrm{IoP}$ \\
\hline Scincidae & Sigaloseps deplanchei & SUB & & Restricted to south of SUB \\
\hline Scincidae & Sigaloseps ruficauda & SUB & & Restricted to ranges of SUB \\
\hline Scincidae & Sigaloseps balios & SUB & & Restricted to ranges of SUB \\
\hline Scincidae & Sigaloseps ferrugicauda & SUB & & Restricted to ranges of SUB \\
\hline Scincidae & Sigaloseps pisinnus & SUB & & Restricted to ranges of SUB \\
\hline Scincidae & Sigaloseps conditus & SUB & & Restricted to ranges of SUB \\
\hline Scincidae & Simiscincus aurantiacus & SUB & & Restricted to south of SUB \\
\hline Scincidae & Tropidoscincus aubrianus & GT & IoP & Widespread across GT $+\mathrm{IoP}$ \\
\hline Scincidae & Tropidoscincus variabilis & SUB & & Widespread across SUB \\
\hline
\end{tabular}

Note: The presence of Epibator greeri in southern New Caledonia is based on photographic images (Deuss, unpublished; VALE Nouvelle-Calédonie unpublished; Jean-Louis Ruiz), and similarly that of Caesoris novaecaledoniae is based on an image on the Endemia website of an individual from Mont Dore (http://endemia.nc/faune).

Note: The record of Bavayia crassicollis reported by Geneva et al. (2013) from Île des Pins is not included here as it is considered to likely represent a recent human-mediated introduction and not native to the region. 
specific with taxa known from Grande Terre has yet to be determined. Of the six species shared between southern Grande Terre and the Île des Pins, one, Cryptoblepharus novocaledonicus, is a coastal specialist (not a member of the Tasmantis radiation, sensu Smith et al. 2007) and four, Caledoniscincus haplorbinus, C. atropunctatus, Epibator nigrofasciolatus, and Phoboscincus garnieri, are "generalist" species with widespread distributions in the territory and known to occur in a range of habitats (including secondary associations) on both ultramafic and non-ultramafic surfaces. The presence of these "generalist" species on both the Île des Pins and the Grande Terre is not surprising given these taxa also occur on the Loyalty Islands, which have never shared a land connection to the Grande Terre, indicating they have good overwater dispersal abilities (although it is possible some might have been inadvertent introductions). The remaining species found on the Île des Pins that is also widespread on Grande Terre is Tropidoscincus aubrianus, an enigmatic species in that it appears to be a generalist in habitat preferences but has only been recorded sporadically, and has not been found on ultramafic surfaces. The affinities of the Sigaloseps recently recorded on Île des Pins has yet to be determined. It would appear to be aligned with Sigaloseps deplanchei, a species generally regarded as restricted to habitats on the ultramafic surfaces of southern Grande Terre (Sadlier et al. 2014a), but which has also been recorded from coastal forest habitat fringing ultramafic surfaces (Port Boise and Yate), these occurrences being regarded as a localized extension of populations resident on the nearby ultramafic surfaces. However, the presence of a species of Sigaloseps on the Île des Pins in habitat on non-ultramafic surfaces indicates that the habitat preferences for species in the genus may be broader than initially thought. The implications for a sight record for Nannoscincus on the Île des Pins (Deuss, pers. obs.) remain uncertain until the identity of the species can be determined. Four species of Nannoscincus occur in the southern ultramafic bioregion. Two of these, N. fuscus and N. mariei, are known only from ultramafic surfaces, the former primarily from habitat on the ranges and the latter from habitat on the ultramafic plateau and adjacent interior ranges in the far south of the bioregion. The other two species of Nannoscincus have more localized distributions, $N$. garrulus having only been recorded from high elevation forest habitat on ultramafic surfaces in the far north of the bioregion, whereas the population of $N$. gracilis in the bioregion is known only from several low elevation sites on coastal non-ultramafic surfaces and the base of the ultramafic surfaces near Nouméa and on the southwest coast.

Aside from the two possible exceptions just discussed, the number of species recorded from the south of the Grande Terre that are restricted to ultramafic surfaces, but absent from the Île des Pins, is extensive, and even when narrow-range localized endemic taxa are excluded comprises nine skinks and four geckos, a number of which are found across a broad range of habitat types on ultramafic surfaces. One possible explanation to account for this anomaly is the absence of suitable habitat on the Île des Pins for many of the taxa restricted to habitats on ultramafic surfaces.

The giant gecko Correlophus sarasinorum is widespread in the south of the bioregion but absent from the Île des Pins. In southern Grande Terre it has only been recorded from humid forest, and its absence from the Île des Pins may lie in its preference for a particular type or level of development of humid forest not found there. The giant gecko Correlophus ciliatus has been recorded from humid forest habitat on the Île des Pins and in southern Grande Terre, and seasonally dry vallicole forest in the north of Grande Terre. Similarly, Mniarogekko chaboua is known from humid forest habitat in southern Grande Terre and assumed to occur in this habitat type on the Île des Pins; its counterpart in northern Grande Terre, Mniarogekko jalu, is also known to inhabit seasonally dry vallicole forest. As such, the species $C$. ciliatus and $M$. chaboua would appear to be able to occupy a broader range of forest types, whereas Correlophus sarasinorum appears to be constrained to well-developed humid forest (Sadlier pers. obs.), subtleties in biology that may have contributed to these species' presence or absence on Île des Pins. Although humid forest habitat is present today on Île des Pins, the forest type that 
existed on the island and/or areas of emergent "land-bridges" connecting southern Grande Terre to the Ile des Pins during historically drier periods when sea levels were lower, may have been structurally different, and while (by inference) able to provide the microhabitat (sheltering and foraging sites) required by $C$. ciliatus and $M$. chaboua, may not have reached the level of development seen in humid forest of southern Grande Terre as required by Correlophus sarasinorum.

However, the absence from the Île des Pins of a number of species restricted to ultramafic surfaces but with distributions that extend across the whole of the southern ultramafic region and occur in a range of both forest and maquis habitats (Bavayia septuiclavis, Eurydactylodes symmetricus, Caledoniscincus notialis, Tropidoscincus variabilis) may not only lie in the unsuitability of habitat present on the Île des Pins now or historically, or of that on historical land bridges that once connected the regions, but also in the response of lizards endemic to southern ultramafic regions to drier conditions associated with historical glacial periods. Contraction of range to mesic refuges during historically drier periods has been proposed as a process that has driven intraspecific lineage diversification of lizards in the Wet Tropics region of Australia during the Pleistocene, and deeper species-level diversification earlier in the Miocene (Schneider et al. 1998; Schneider and Moritz 1999; Moritz et al. 2012). Similar processes have been proposed in the evolution of elements of the lizard fauna on the ultramafic surfaces of New Caledonia, leading to regionally and massif-specific endemic species in the genera Marmorosphax (Sadlier et al. 2009) and Sigaloseps (Sadlier, Bauer et al. 2014b). Under such conditions certain species in southern New Caledonia restricted to habitats on ultramafic surfaces may have contracted in range rather than expand and migrate to the Ille des Pins via emergent land across the channel that now separates the island from Grand Terre. In this context the evolutionary relationships of Kuniesaurus albiauris n. sp. may lie with morphologically similar taxa capable of occupying both ultramafic and non-ultramafic surfaces rather than those with the apparent limitations associated with evolution on ultramafic surfaces. However, these comments are made with the caveat that only limited survey work for lizards has been undertaken on the island's ultramafic surfaces, and the only area that has been investigated in detail, Pic N'Ga, has undergone significant modification through a high level of deforestation and burning, with almost half the plateau area converted to pine plantation. Clearly, targeted and systematic survey work for lizards is required on both the forest areas in the west of the island and on the remaining natural habitat on its ultramafic surfaces in order to fully assess the diversity of the lizard fauna of the Île des Pins in a regional context, and its role as a hotspot for lizards within the New Caledonian biodiversity hotspot.

\section{ACKNOWLEDGMENTS}

The authors thank the Direction de l'Environnement Province Sud for the financial and logistic support provided to IRD to undertake research on the Île des Pins which included studies on the region's lizard fauna, in particular Isabelle Jurquet, Manina Tehei, Caroline Groseil and Cendrien Meresse. AMB was supported by National Science Foundation grant DEB 1555968 and by the Gerald M. Lemole Endowed Chair Funds from Villanova University.

\section{Literature Cited}

Balouet, J., and S. Olson. 1989. Fossil birds from late Quaternary deposits in New Caledonia.Smithson. Contr.Zool.469:1-38.

Bauer, A. M., and R. A. Sadlier. 1993. Systematics, biogeography and conservation of the lizards of New Caledonia. Biodivers. Lett. 1:107-122.

Bauer A. M., and R. A. Sadlier. 1994. The terrestrial herpetofauna of the Ile des Pins, New Caledonia. Pac. Sci. 48 (4): 353-366.

Bauer A. M., T.Jackman, R. A. Sadlier, G. Shea, and A. H. Whitaker. 2008. A new smallbodied species of Bavayia (Reptilia: Squamata: Diplodactylidae) from southeastern New Caledonia. Pac. Sci. 62 (2): 247-256. 
Bauer, A. M., T. Jackman, R. A. Sadlier, and A. H. Whitaker. 2012. Revision of the giant geckos of New Caledonia (Reptilia: Diplodactylidae: Rhacodactylus). Zootaxa 3404:1-52.

Bauer A. M., R. A. Sadlier, T. Jackman, and G. Shea. 2012. A new member of the Bavayia cyclura species group (Reptilia: Squamata: Diplodactylidae) from the southern ranges of New Caledonia. Pac. Sci. 66 (2): 239$-247$.

Böhme, W. 1976. Über die Gattung Eugongylus Fitzinger, mit Beschreibung einer neuer Art (Reptilia: Scincidae). Bonn. Zool. Beitr. 27:245-251.

Chapple, D. G., P. A. Ritchie, and C. H. Daugherty. 2009. Origin, diversification and systematics of the New Zealand Skink fauna (Reptilia: Scincidae). Mol. Phylogenet. Evol. 52:470-487.

Dubois, J., J. Launay, and J. Recy. 1974. Uplift movements in New Caledonia, Loyalty Islands area and their plate tectonics interpretation. Tectonophysics 24:133-150.

Geneva, A., A. M. Bauer, R. A. Sadlier, and T. R. Jackman. 2013. Terrestrial herpetofauna of Île des Pins, New Caledonia, with an emphasis on its surrounding islands. Pac. Sci. 67 (4): 571-590.

Greer, A. E. 1979. A phylogenetic subdivision of Australian skinks. Rec. Aust. Mus. 32:339-371.

Honda, M., H. Ota, M. Kobayashi, J. Nabhitabhata, H.-S. Yong, and T. Hikida. 2000. Phylogenetic relationships, character evolution, and biogeography of the subfamily Lygosominae (Reptilia: Scincidae) inferred from mitochondrial DNA sequences. Mol. Phylogenet. Evol. 15:452-461.

Ineich, I. 2009. Bocourt's terrific skink, Phoboscincus bocourti Brocchi, 1876 (Squamata, Scincidae, Lygosominae). In Grandcolas P. (ed.), Zoologia Neocaledonica, 7. Biodiversity studies in New Caledonia. Mém. Mus. Natl. Hist. Nat. 198:149-174. Ineich, I., R. Sadlier, A. M. Bauer, T. R. Jackman, and S. A. Smith. 2014. Bocourt's terrific skink, Phoboscincus bocourti (Brocchi, 1876), and the monophyly of the genus Phoboscincus Greer, 1974. In É. Guilbert, T.
Robillard, H. Jourdan, and P. Grandcolas (eds.), Zoologia Neocaledonica 8. Biodiversity studies in New Caledonia. Mém. Mus. Natl. Hist. Nat. 206:69-79.

IUCN. 2017. The IUCN Red list of threatened species 2001 categories \& criteria (version 3.1). http://www.iucnred list.org/technical-documents/categoriesand-criteria/2001-categories-criteria.

Jourdan, H., F. Rigault, J. M. Boré, and E. Vidal. 2011. Redécouverte de Myrmecia apicalis, fourmi endémique « archaïque » menacée d'extinction. Premier éléments pour une proposition de classement en espèce protégée. Rapport de Convention de Recherche avec la province sud, IRD IMBE, Nouméa, 18 pp.

Jourdan, H., A. Gérard, E. Muret, K. Neal, T. Ghandforoush, L. Debar, H. de Meringo, S. Scussel, A. Millon, and E. Vidal. 2012. Etude de la faune des reptiles de l'Île des Pin et des îlots périphériques: enjeux de conservation et interactions avec les principales espèces animales envahissantes. Rapport de Convention de Recherche avec la province sud, IRD IMBE, Nouméa, 26 pp.

Jourdan, H., M. Manceau, L. Debar, F. Rigault, A. Gérard, and H. de Meringo, 2013. Etude de la faune des reptiles de l'île des Pins et des îlots périphériques: enjeux de conservation et interactions avec les principales espèces animales envahissantes. Rapport de Convention de Recherche avec la province sud, IRD IMBE, Nouméa, 37 pp.

Jourdan, H., H. de Méringo, A. S. Millot, and P. Machful. 2014. Enjeux de conservation des reptiles de l'Île des Pins et des îlots périphériques et interactions avec les principales espèces animales envahissantes. Rapport de Convention de Recherche C 644-14, Province Sud-IRD, IRD IMBE, Nouméa, 31 pp.

Jourdan, H., R. A. Sadlier, and A. M. Bauer. 2001. Little Fire Ant invasion (Wasmannia auropunctata) as a threat to New Caledonian lizards: Evidences from a sclerophyll forest (Hymenoptera: Formicidae). Sociobiology 38 (3A): 283-301.

Monks, J. M., A. Monks, and D. R. Towns. 2014. Correlated recovery of five lizard 
populations following eradication of invasive mammals. Biol. Invasions 16:167-175.

Moritz C., G. Langham, M. Kearney, A. Krockenberger, J. VanDerWal, and S. Williams. 2012. Integrating phylogeography and physiology reveals divergence of thermal traits between central and peripheral lineages of tropical rainforest lizards. Phil. Trans. R. Soc. B 367:1680-1687.

Palmas, P., H.Jourdan, E. Bonnaud, L. Debar, H. De Meringo, E. Bourguet, F. Rigault, M. Mathivet, M. Lee, Y. Papillon, and E. Vidal. 2017. Feral cats threaten the outstanding endemic fauna of the New Caledonia biodiversity hotspot. Biol. Cons. 214:250-259.

Pelletier, B. 2007. Geology of the New Caledonia region and its implications for the study of the New Caledonian biodiversity. In C. Payri and B. Richer de Forges (eds.) Forum BIOdiversité des Ecosystèmes Coralliens. Compendium of marine species from New Caledonia. Documents Scientifiques et Techniques II7:19-32.

Sadlier, R. A. 1986. A review of the scincid lizards of New Caledonia. Rec. Aust. Mus. 39:1-66.

Sadlier, R. A. 2010. Systematic studies of the scincid lizards of New Caledonia. Ph.D. Thesis, Griffith University, Queensland. 199 pp.

Sadlier, R. A., A. H. Whitaker, and A. M. Bauer. 1998. Lioscincus maruia, a new species of lizard (Reptilia: Scincidae) from New Caledonia, southwest Pacific. Pac. Sci. 52:334-341.

Sadlier, R. A., A. M. Bauer and S. A. Smith. 2006. A new species of Nannoscincus Günther (Squamata: Scincidae) from high elevation forest in southern New Caledonia. Rec. Aust. Mus. 58 (1): 29-36.

Sadlier, R. A., S. A. Smith, and A. M. Bauer. 2006. A new genus for the New Caledonian scincid lizard Lygosoma euryotis Werner, 1909 , and the description of a new species. Rec. Aust. Mus. 58 (1): 19-28.

Sadlier, R. A., S. A. Smith, A. M. Bauer, and A. H. Whitaker. 2009. Three new species of skink in the genus Marmorosphax Sadlier (Squamata: Scincidae) from New Caledonia. In Grandcolas P. (ed.), Zoologia
Neocaledonica 7. Biodiversity studies in New Caledonia. Mém. Mus. Natl. Hist. Nat. 198:373-390.

Sadlier, R. A., A. M. Bauer, P. L. Wood Jr., S. A. Smith, and T. R. Jackman. 2013. A new species of lizard in the genus Caledoniscincus (Reptilia: Scincidae) from southern New Caledonia and a revision of Caledoniscincus atropunctatus (Roux). Zootaxa 3694 (6): 501-524.

Sadlier R. A., A. M. Bauer, P. L. Wood Jr., S. A. Smith, A. H. Whitaker, and T. R. Jackman. 2014a. Cryptic speciation in the New Caledonian lizard genus Nannoscincus (Reptilia: Scincidae) including the description of a new species and recognition of Nannoscincus fuscus Günther. In É. Guilbert, T. Robillard, H. Jourdan, and P. Grandcolas (eds.), Zoologia Neocaledonica 8. Biodiversity studies in New Caledonia. Mém. Mus. Natl. Hist. Nat. 206:45-68.

Sadlier, R. A., A. M. Bauer, P. L. Wood Jr., S. A. Smith, A. H. Whitaker, H. Jourdan, and T. Jackman. 2014b. Localized endemism in the southern ultramafic bio-region of New Caledonia as evidenced by the lizards in the genus Sigaloseps (Reptilia: Scincidae), with descriptions of four new species. In É. Guilbert, T. Robillard, H. Jourdan, and P. Grandcolas (eds), Zoologia Neocaledonica 8. Biodiversity studies in New Caledonia. Mém. Mus. Natl. Hist. Nat. 206:79-113.

Sadlier R. A., A. M. Bauer, S. A. Smith, G. M. Shea, and A. H. Whitaker. 2014c. High elevation endemism on New Caledonia's' ultramafic peaks - a new genus and two new species of scincid lizard. In É. Guilbert T. Robillard, H. Jourdan, and P. Grandcolas (eds.), Zoologia Neocaledonica 8. Biodiversity studies in New Caledonia. Mém. Mus. Natl. Hist. Nat. 206:115-125.

Sadlier, R. A., A. M. Bauer, G. M. Shea, and S. A. Smith. 2015. Taxonomic resolution to the problem of polyphyly in the New Caledonian scincid lizard genus Lioscincus (Squamata: Scincidae). Rec. Aust. Mus. 67 (7): 207-224.

Schneider C. J. S., M. Cunningham, and C. Moritz. 1998. Comparative phylogeography and the history of endemic vertebrates 
in the Wet Tropics rainforest of Australia. Mol. Ecol. 7:487-498.

Schneider, C. J. and C. Moritz. 1999. Rainforest refugia and evolution in Australia's Wet Tropics. Proc. Royal Soc. Lond. B 266:191-196.

Smith M. J., H. Cogger, B. Tiernan, D. Maple, C. Boland, and F. Napier. 2012. An oceanic island reptile community under threat: the decline of reptiles on Christmas Island, Indian Ocean. Herp. Conserv. Biol. 7:206-218.

Smith, S. A., R. A. Sadlier, A. M. Bauer, C. C. Austin, and T. Jackman. 2007. Molecular phylogeny of the scincid lizards of New Caledonia and adjacent areas: Evidence for a single origin of the endemic skinks of Tasmantis. Mol. Phylogenet. Evol. 43:1151-1166.

Thibault M., F. Brescia, H. Jourdan, and E. Vidal. 2017. Invasive rodents, an overlooked threat for skinks in a tropical island hotspot of biodiversity. N. Z. J. Ecol. 41 (1): 74-83. doi:10.20417/nzjecol.41.9.

Whitaker, A. H. 1973. Lizard populations on islands with and without Polynesian rats, Rattus exulans (Peale). Proc. N. Z. J. Ecol. Soc. 20:121-130. 